\title{
The Response of International Campaign to Ban Landmines (ICBL) to Resolve the Problem of Humanitarian Issue
}

\author{
Alfredha Shinta Putri \\ Magister of International Relations, Universitas Muhammadiyah Yogyakarta - Indonesia \\ Email: alfredha.shinta@yahoo.com \\ Submitted: 10 April 2019 | Accepted: 24 April 2019
}

\begin{abstract}
Penelitian ini bertujuan untuk menjelaskan peran Organisasi Internasional Non-Pemerintah (INGO) yang bernama ICBL (International Campaign to Ban Landmines). NGO ini memiliki tujuan untuk mengatasi permasalahan ranjau darat dan explosive remnants of war di dunia yang dipandang sebagai permasalahan darurat dan genting. Adapun alasan mengapa ranjau darat dan explosive remnants of war adalah karena sangat membahayakan manusia maupun hewan. Oleh karena itu, ICBL mengajak negara-negara di dunia untuk melakukan kesepakatan dan perjanjian internasional dalam melarang penggunaan dan produksi ranjau darat melalui The Mine Ban Treaty yang disepakati pada tahun 1997. Upaya dari ICBL ini mendapat dukungan dari organisasi internasional seperti PBB dan advocacy networks lainnya. Meskipun demikian, pelarangan dan produksi ranjau darat serta tata kelola mengenai hal ini masih menghadapi sejumlah tantangan dan hambatan yang disebabkan oleh ketidaksediaan negara-negara besar untuk menandatangani dan meratifikasi perjanjian The Mine Ban Treaty. Akan tetapi, walaupun masih menghadapi beberapa tantangan dan hambatan, ICBL bisa dikatakan mampu untuk mengurangi jumlah ranjau darat yang ada di dunia. Dalam penelitian ini digunakan data-data sekunder yang diperoleh dari buku, jurnal, artikel cetak dan online.
\end{abstract}

Kata kunci: ICBL, NGO, Ranjau Darat, The Mine Ban Treaty.

\begin{abstract}
Abstrak
This research aims to explain the role of International Non-Governmental Organization (INGO) namely ICBL (International Campaign to Ban Landmines). The objective of ICBL to overcome the problem of landmines as an emergency problem and critical issue in the world. This matter is because the effect of landmines and explosive remnants of war is very dangerous for humans, animals, and other living things. Otherwise, ICBL engage all of the states in the world to ratify an international agreement to ban using and producing landmine through The Mine Ban Treaty which agreed in 1997 by the states in the world. The efforts of ICBL are supported by United Nations and other advocacy networks. The obstacles arise from the unwillingness of great power to sign and ratify The Mine Ban Treaty. But, although still deal with some obstacles and challenges, ICBL able to decrease the amount of landmines in the world today. The research used secondary sources collected from books, journal, article, or other related-website.
\end{abstract}

Keywords: ICBL, NGO, landmines, The Mine Ban Treaty.

\section{PENDAHULUAN}

Today, landmines and explosive remnants of war (ERW) can be said to be an emergency and critical issues in international world. This is because the effect of landmines and explosive remnants of war are very dangerous for human, animal, or other living things. Although there are many peace 
agreements and the war are stopped, landmines and explosive remnants of war still many left over in former war area. Landmines and explosive remnants of war cannot be detected by the society, because they are located hidden in the ground. Without the specific tools, landmines and explosive remnants of war cannot be detected its existence. So unconsciously, if there is human that walk in former war area, then most likely that human can attached the landmines and explosive remnants of war. This is because the landmines and explosive remnants of war still active. The effect explosion of landmines and explosive remnants of war can attack civilians, children, woman, or soldiers. The explosion of landmines and explosive remnants of war make the human can lose their limb, seriously injured, or dead. That is the illustration of the dangerous of landmines and explosive remnants of war in this world today, although the situation in the world today is minim of war.

Landmines and explosive remnants of war are different. Explosive remnants of war are weaponry that left after conflict. Explosive weapon that failed explode are called UXO (unexploded ordnance). This weapon is left after conflict and created danger that similar with landmines. AXO (abandoned explosive ordnance) is explosive weapon that used during armed conflict yet, but has been abandoned and no longer effectively controlled. ERW include artillery shells, grenades, mortars, rockets, bombs, and remaining ammunition. Based on the definition of international law, ERW are consists of UXO and AXO, but not landmines.

Landmines and ERW can pose a serious threat and sustainable for civilians. These weapons can be found on roads, trails, farmer fields, forests, deserts, along borders, and in other places where people carry out their daily activities. These weapons cause fear in the community. One of the efforts of the state to reduce the impact of landmines is that countries must spend money to clear mines. The problem of landmines is quite a serious problem, because it takes a lot of casualties.

\section{LITERATURE REVIEW}

\section{Building A Norm: The Banning of the Anti-Personnel Landmines by Angela Neufeld}

According to Neufeld (2005), anti-personnel landmines were one of the military weapons in the war era. The problem of landmines is related to humanitarian issues. Then, NGOs campaigned to make international agreements in the ban on the use of landmines. The Ottawa Treaty emerged in 1997. This agreement 
established an international norm to ban the use of landmines. With this agreement, "NGOs" have a legal basis to ban the use of landmines in the international world. Landmines have a negative impact on humans, especially in ex-war countries. Negative impacts such as loss of life, disability, etc. ICBL as an NGO is able to form an international political environment in the prohibition of using landmines. ICBL can also be referred to as the international agenda setting. The ICBL seeks to resolve the problems of the humanitarian crisis that have occurred.

ICBL as an NGO, not only builds a treaty, but also tries to make an international standard of behavior or norms in the prohibition of using landmines (Angela, 2000). Angela argued that there were several factors that made the Ottawa Convention successful and supported the establishment of a norm (Angela, 2000). The first factor is the existence of traditions of humanitarian law and norms that are based on proportional principles, discrimination, superfluous injury, and principles that prohibit the use of landmines. Humanitarian norms provide international legal precedent for landmine norms. Second, the ICBL encourages the prohibition of landmines where it is able to provide an international platform. Third, the Ottawa Process forms a catalytic environment that supports the formation of a norm because Canadian leadership is a momentum in forming an agreement. These factors not only formed the Ottawa Convention, but also tried to form a norm.

Angela also argued that the current trend shows that norms try to achieve wide degree of support and modify the behavior of landmine actors (Angela, 2000). But sometimes, foreign policy in a country does not reflect this. In addition to this, Angela saw that the realist framework was unable to explain the country's desires in prohibiting the use of landmine through the Ottawa Convention. In this case, it is the constructivist framework that can explain the formation of a norm. Humanitarian law is closely related to the human rights side. Angela explained that the constructivist approach sees the state as a social actor, where interests and behavior will be governed by rules and norms. The state's identity and interests will be socially construct and intersubjective. So, state behavior will reflect a norm on an issue. Angela explained that the Ottawa Convention codified an international norm in the use of landmines. 


\section{Ban Landmines: The Social Construction of the International Ban on Anti-Personnel Landmines 1991-2001 by Robert J. Lawson}

The author tries to explain social construction. Robert argues that the state can be interpreted as "social structure", where it becomes a collection of material and knowledge based on practices and actions carried out by people (Robert, 2002). The state can do many things like humans do, including learning (Robert, 2002). Changes in state behavior can be seen from the learning process of the actors being operated into the international system level to be able to produce new norms, in which the state is involved in international policy formulation. Norms will form interests and interests will shape actions. Norms have the power to shape the country's perceptions of an interest and this will shape the behavior of the country itself. The author uses Jepperson, Wendt, and Katzenstein's viewpoints the central lines of constructivist arguments that state identity is a significant variable in forming norms as a concept of national interest and state policy.

International behavior is structured from material and knowledge based on practice. The expression of international norms is a codification of ratified international legal instruments. So that international law must consist of the issue of land mines. International humanitarian law is able to recognize the central role of norms that shape state behavior (Robert, 2002). Norms help in the social construction process in international relations from a legal perspective. Constructivist theory is used in explaining this paper.

\section{The Norm against Anti-Personnel Landmines: A Case Study of Finland's Accession to the Ottawa Convention by Elijah J. M Elenius}

The author explains why Finland joined in the Ottawa Convention. This is because of moral persuasion (Elenius, 2012). Actors in the world are not only morally persuaded or internalized into a new norm, but because of the given identity. The author also explains the developmental process of specific norms against antipersonnel landmines (Elenius, 2012).

In this case, Finland has been an advocacy for humanitarian assistance for a long time and this can be a picture of Finland's own image. The author also argues that the theoretical approach in this paper as sociological institutionalism (Elenius, 2012). The prohibition on the use of landmines is based on international humanitarian law. Elijah also used the NGO concept in explaining his writing. In this case, ICBL as an NGO is able to form an 
agenda setting in the international world.

\section{METHODOLOGY}

\section{The Type of Research}

The type of research that used in this journal is using descriptive research methods. Descriptive research is a study that aims to obtain an overview of a particular time.

\section{The Method of Collecting Data}

This study uses secondary data collection techniques. This technique of collecting data use library materials, journals, books, articles, and newspaper. The addition of data can also get from internet or relevant website with this research.

\section{RESULTS}

\section{Development of ICBL}

The ICBL (International Campaign to Ban Landmines) is an NGO which has the main goal that the world is being free of landmines and ERW, where residents are not afraid to walk on mines, children can play without mistaking unexploded submunitions for toys, and the community does not bear the social and economic impacts of the ERW's presence over the next few decades. ICBL is a global network that works in 100 countries locally, nationally and internationally to destroy antipersonnel mines. Jody Williams is the founder of ICBL, where she won the Nobel Peace Prize in 1997, because she was able to form the Mine Ban Treaty. This campaign is loose and flexible among its members.

ICBL was formed in 1992 by six NGO groups namely Handicap International, Human Rights Watch, Medico International, the Mines Advisory Group, Physicians for Human Rights, and Vietnam Veterans of America Foundations. These NGOs work in the continents of Asia, Africa, the Middle East and Latin America. The main objective of the establishment of the ICBL is to find a comprehensive solution to resolve the crisis caused by landmines. The ICBL also brings values in other fields, namely in the human rights sector, children's rights, development issues, refugee issues, media and humanitarian assistance. Members of the ICBL also relate to other NGOs to spread the vision of the ICBL through their networks. The ICBL organizes campaign events and conferences in many countries to raise awareness the problem of landmines and the prohibition on it. In addition, ICBL also provides training for new campaigners to enable them become effective advocates in their country. ICBL membership is currently growing very fast.

The ICBL works to promote global norms to ban using of mines, 
especially for countries that signed the agreement. ICBL focuses on implementing the Mine Ban Treaty. In this case, ICBL also collaborates with government, international organizations and other NGOs. In 2011, ICBL also joined the CMC (Cluster Munition Coalition) namely ICBL-CMC. However, both of them continue to do different campaigns.

This ICBL-CMC can be said that it is a monitoring regime of the Mine Ban Treaty and the Convention on Cluster Munitions. They monitor and report on state parties' implementation and compliance with the Mine Ban Treaty and the Convention on Cluster Munitions and respond to humanitarian problems caused by landmines, gunpowder and ERW. This relationship shows a synergic, systematic and sustainable collaboration to monitor humanitarian law or disarmament treaties. Before becoming ICBL-CMC, initially in June 1998, ICBL on its initiative formed the Landmine Monitor. Then in 2010, Landmines Monitor changed to Landmine and Cluster Monitor Munitions (often called The Monitor).

\section{The States That Using of Landmines}

The states that still use landmines until now are Myanmar, Syria, Afghanistan, India, Iraq, Nigeria, Pakistan, Ukraine and Yemen. In
Myanmar, landmine users are the government itself, which is called Tatmadaw. In addition to Myanmar, the use of landmines by the government is also carried out in Syria. In Pakistan, India, Afghanistan, Iraq, Nigeria, Ukraine and Yemen the use of landmines is carried out by the nonstate armed group.

\section{The Causalities of Landmines}

Regarding causalities from landmine explosions or ERW, in 2016, The Monitor reported that there were 8.605 people attacked by landmine or ERW explosions and there were 2.089 people had been killed. Most of the people attacked by landmine or ERW explosions are mostly in Afghanistan, Libya, Ukraine, Angola, Azerbaijan, Bosnia-Herzegovina, Cambodia, Chad, Croatia, Iraq, Thailand, Turkey, and Yemen. Based on reports from ICBL, around $78 \%$ of victims of landmines or ERWs are civilians, $42 \%$ are children, and $16 \%$ are women (see diagram 1).

Diagram 1: Number of Causalities as a Result of Landmine Explosions from Year to Year

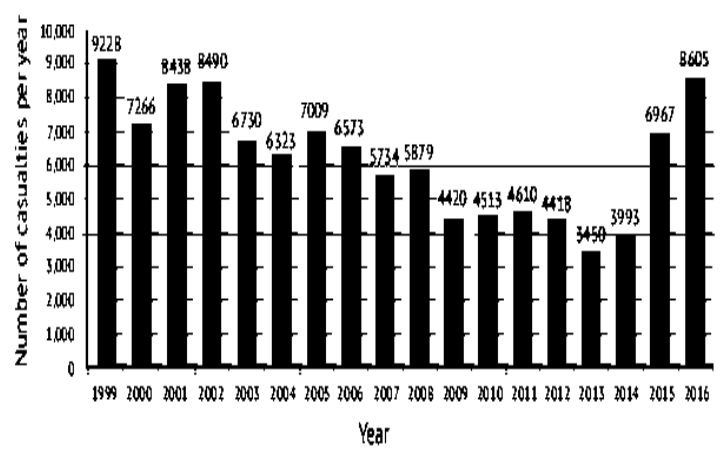

Source: Landmine Monitor 2017. Geneva: International Campaign to Ban Landmines. p. 52 
The diagram show that the causalities due to landmine explosions from 1999 until 2016 is fluctuated. But the highest point from causalities due to landmine explosions is happened on 1999, and the highest number of causalities is never happened again after that year. This is because there is the effort of ICBL to resolve the problem of landmine.

Diagram 2: Comparison of Causalities Due to Landmine Explosions

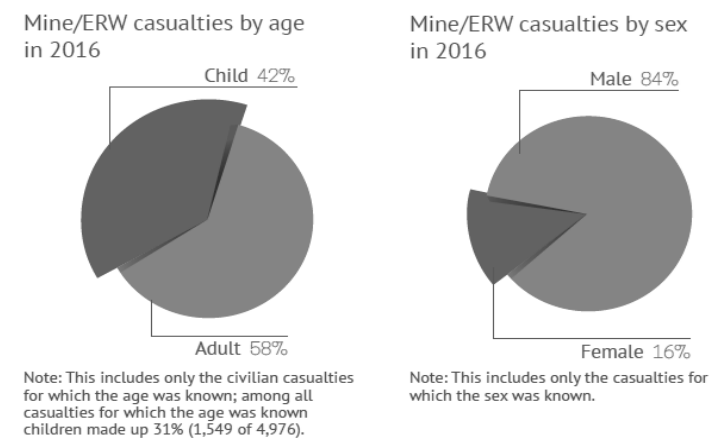

Source: Research Team Leader. (2017). Landmine Monitor 2017. Geneva: International Campaign to Ban Landmines. p. 56.

From the number of causalities, it can be seen the comparison of causalities caused by landmine explosions, both in terms of sex and age. In 2016 for example, most of the victims of landmine explosions in terms of age were adults, and in terms of sex most of the victims were men (Research Team Leader, 2017). This can be seen in the diagram below.

\section{International Agreements between the States and ICBL}

There are agreements and international agreements to ban landmines and ERW. Examples of agreements on banning landmines and ERW are the 1997 Mine Ban Treaty (Convention on the Prohibition of Use, Stockpiling, Production and Transfer of Anti-Mines and on their Destruction) signed in Ottawa, Canada providing a good framework for the government to alleviate the suffering of civilians living in areas affected by land mines. The government that joins this agreement must stop the use, stockpiling and production of antipersonnel mines. They must destroy all antipersonnel mines stored within 4 years and clear all antipersonnel mines in all regions within 10 years. The countries that are part of it must also provide assistance to survivors and community landmines to support risk education programs of landmines and ERW. In this case there must be also cooperation between NGOs and the government.

The Mine Ban Treaty was signed on December 3, 1997 in Ottawa Canada. The countries that signed the agreement must be obliged to comply with the applicable rules. At present there are 162 countries that have ratified the international agreement The Mine Ban Treaty (see Table 1). 
Table 1: States that Join in the Convention on the Prohibition of the Use, Stockpiling, Production and Transfer of Anti-Personnel Mines and on their Destruction

\begin{tabular}{|c|c|c|c|}
\hline Continent & State Parties & Signatory & Non-Signatory \\
\hline $\begin{array}{l}\text { Europe, the } \\
\text { Caucasus and } \\
\text { Central Asia }\end{array}$ & $\begin{array}{l}\text { Albania, Andorra, Austria, Belarus, Belgium, Bosnia \& } \\
\text { Herzegovina, Bulgaria, Croatia, Cyprus, Czech Republic, } \\
\text { Denmark, Estonia, Finland, France, Germany, Greece, Holy } \\
\text { See, Hungary, Iceland, Ireland, Italy, Latvia, Liechtenstein, } \\
\text { Lithuania, Luxembourg, Macedonia, Malta, Moldova, Monaco, } \\
\text { Montenegro, Netherlands, Norway, Poland, Portugal, } \\
\text { Romania, San Marino, Serbia, Slovakia, Slovenia, Spain, } \\
\text { Sweden, Switzerland, Tajikistan, Turkey, Turkmenistan, } \\
\text { Ukraine United Kingdom. }\end{array}$ & - & $\begin{array}{l}\text { Armenia, Azerbaijan, } \\
\text { Georgia, Kazakhstan, } \\
\text { Kyrgyzstan, Russia, } \\
\text { Uzbekistan }\end{array}$ \\
\hline The Americas & $\begin{array}{l}\text { Antigua \& Barbuda, Argentina, Bahamas, Barbados, Belize, } \\
\text { Bolivia, Brazil, Canada, Chile, Colombia, Costa Rica, } \\
\text { Dominica, Dominican Rep, Ecuador, El Savador, Grenade, } \\
\text { Guatemala, Guyana, Haiti, Honduras, Jamaica, Mexico, } \\
\text { Nicaragua, Panama, Paraguay, Peru, St. Kitts \& Nevis, Saint } \\
\text { Lucia, St. Vincent \& the Grenadines, Suriname, Trinidad \& } \\
\text { Tobago, Uruguay, Venezuela. }\end{array}$ & & Cuba, United States \\
\hline $\begin{array}{l}\text { Middle East } \\
\text { \& North } \\
\text { Africa }\end{array}$ & $\begin{array}{l}\text { Algeria, Iraq, Jordan, Kuwait, Oman, Palestine, Qatar, Tunisia, } \\
\text { Yemen. }\end{array}$ & - & $\begin{array}{l}\text { Bahrain, Egypt, Iran, } \\
\text { Israel, Lebanon, Libya, } \\
\text { Morocco, Saudi Arabia, } \\
\text { Syria, United Arab } \\
\text { Emirates. }\end{array}$ \\
\hline $\begin{array}{l}\text { East \& South } \\
\text { Asia \& the } \\
\text { Pacific }\end{array}$ & $\begin{array}{l}\text { Afghanistan, Australia, Bangladesh, Bhutan, Brunei } \\
\text { Darussalam, Cambodia, Cook Islands, Fiji, Indonesia, Japan, } \\
\text { Kiribati, Malaysia, Maldives, Nauru, New Zealand, Nieu, } \\
\text { Palau, Papua New Guinea, Philippines, Samoa, Solomon } \\
\text { Islands, Sri Lanka, Thailand, Timor-Leste, Tuvalu, Vanuatu. }\end{array}$ & $\begin{array}{l}\text { Marshall } \\
\text { Islands }\end{array}$ & $\begin{array}{l}\text { China, India, North } \\
\text { Korea, South Korea, Lao } \\
\text { DPR, Fed States of } \\
\text { Micronesia, Mongolia, } \\
\text { Myanmar, Nepal, } \\
\text { Pakistan, Singapore, } \\
\text { Tonga, Vietnam }\end{array}$ \\
\hline $\begin{array}{l}\text { Sub-Saharan } \\
\text { Africa }\end{array}$ & $\begin{array}{l}\text { Angola, Benin, Botswana, Burkina Faso, Burundi, Cameroon, } \\
\text { Cape Verde, Central African Rep, Chad, Comoros, Republic } \\
\text { Congo, Cote d'Ivoire, Democratic Republic Congo, Djibouti, } \\
\text { Equatorial Guinea, Eritrea, Eswatini, Ethiopia, Gabon, } \\
\text { Gambia, Ghana, Guinea, Guinea-Bissau, Kenya, Lesotho, } \\
\text { Liberia, Madagascar, Malawi, Mali, Mauritania, Mauritius, } \\
\text { Mozambique, Namibia, Niger, Nigeria, Rwanda, Sao Tome \& } \\
\text { Principe, Senegal, Seychelles, Sierra Leone, Somalia, South } \\
\text { Africa, South Sudan, Sudan, Tanzania, Togo, Uganda, Zambia, } \\
\text { Zimbabwe. }\end{array}$ & & \\
\hline
\end{tabular}

\section{Notes:}

- State parties are states that ratified or acceded the Ottawa Convention.

- Signatories are state that signed the Ottawa Convention but not yet ratified the Ottawa Convention.

- Non-signatories are state that not yet acceded the Ottawa Convention

\section{Financial Management Within the ICBL}

Financial funding support for ICBL comes from international contributions, donors, and national contributions. Countries that become top five donor states in order to support the objectives of the ICBL are the United States, European Union, Japan, Germany and Norway. These countries contributed $70 \%$ in contributing funds to the ICBL. The 
amount of funds they provided to ICBL was approximately US $\$ 335.6$ million in 2016. This number increased from 2015, because Japan and Germany increased the amount of funds given to ICBL about US \$55 million (Research Team Leader, 2016). While the top five recipient states of the ICBL are Iraq, Afghanistan, Croatia, Cambodia, and Laos. Funds that given to these countries amounted approximately US $\$ 258.7$ million. Iraq is the country that receive the most funding compared to the other four countries. The total amount of funds collected to solve the issue of landmine problems in 2016 was US $\$ 564.5$ million. This amount of funds increased from 2015, approximately to US $\$ 39.3$ million (7\%) (see Table 2).

Table 2: Contributions from donor countries from 2012-2016

\begin{tabular}{|c|c|c|c|c|c|c|}
\hline \multirow{2}{*}{ Donor } & \multicolumn{5}{|c|}{ Contribution (US\$ million) } & \multirow{2}{*}{ Total } \\
\hline & 2016 & 2015 & 2014 & 2013 & 2012 & \\
\hline US & 152.1 & 159.4 & 113.1 & 113.4 & 134.4 & 672.4 \\
\hline EU & 73.8 & 40.8 & 66.8 & 39.6 & 60.7 & 281.7 \\
\hline Japan & 40.7 & 49.3 & 49.1 & 64.0 & 57.6 & 260.7 \\
\hline Germany & 37.3 & 15.2 & 17.5 & 22.1 & 23.8 & 115.9 \\
\hline Norway & 31.7 & 22.3 & 41.8 & 49.6 & 48.4 & 193.8 \\
\hline Netherlands & 25.2 & 22.1 & 25.9 & 23.4 & 24.1 & 120.7 \\
\hline UK & 24.9 & 15.4 & 13.1 & 22.8 & 22.0 & 98.2 \\
\hline Switzerland & 16.6 & 17.4 & 18.1 & 20.6 & 18.4 & 91.1 \\
\hline Canada & 13.3 & 10.8 & 7.7 & 7.9 & 6.8 & 46.5 \\
\hline New Zealand & 12.5 & 3.2 & 7.5 & 6.7 & 5.4 & 35.3 \\
\hline Australia & 11.1 & 4.1 & 6.6 & 14.5 & 24.0 & 60.3 \\
\hline Denmark & 10.2 & 9.2 & 12.1 & 9.3 & 8.7 & 49.5 \\
\hline Sweden & 6.5 & 6.1 & 7.8 & 12.9 & 14.1 & 47.4 \\
\hline $\mathrm{OCHA}$ & 4.1 & 0.4 & 0 & 0 & 0 & 4.5 \\
\hline Ireland & 3.3 & 3.6 & 4.5 & 4.1 & 3.6 & 19.1 \\
\hline France & 3.2 & 1.1 & 1.3 & 2.1 & 2.0 & 9.7 \\
\hline Belgium & 2.9 & 0.3 & 3.2 & 3.1 & 7.2 & 16.7 \\
\hline Italy & 2.8 & 3.0 & 2.2 & 1.5 & 2.8 & 12.3 \\
\hline South Korea & 2.5 & 0.3 & 0.2 & 0.1 & 0.2 & 3.3 \\
\hline Luxembourg & 1.3 & 1.6 & 1.5 & 1.9 & 1.2 & 7.5 \\
\hline Austria & 1.1 & 0.02 & 0.02 & 1.2 & 2.3 & 4.6 \\
\hline Other donors & 2.4 & 8.4 & 11.8 & 19.6 & 31.2 & 73.4 \\
\hline Total & 479.5 & 394.0 & 411.8 & 440.4 & 498.9 & 2224.6 \\
\hline
\end{tabular}

Source: Research Team Leader. 2017. Landmine Monitor 2017. Geneva: International Campaign to Ban Landmines. p. 87.

The table show the financial donor country for ICBL. The top five donor country are United States, European Union, Japan, Germany, and Norway. Those all of countries are the states that give the biggest financial contribution to ICBL (see Table 3).

Table 3: List of National Support Countries in 2016 National support: 2016

\begin{tabular}{lr} 
States & $\begin{array}{c}\text { Cantribution } \\
\text { (US\$ miltion) }\end{array}$ \\
\hline Croatia & 26.4 \\
\hline Angala & 24.5 \\
\hline BiH & 10.7 \\
\hline Lebanon & 9.0 \\
\hline Chile & 5.8 \\
\hline Chad & 2.8 \\
\hline Mauritania & 2.4 \\
\hline Sudan & 2.0 \\
\hline Lad PDR & 0.8 \\
\hline Zimbabwe & 0.5 \\
\hline Ecuador & 0.1 \\
\hline Total & $\mathbf{8 5 . 0}$
\end{tabular}

Source: Research Team Leader. 2017. Landmine Monitor 2017. Geneva: International Campaign to Ban Landmines.

Table 3 shows the states that give financial support to its states for resolving the problem of landmine. It shows that the government are supporting to resolve the problem of landmine especially in their state. The top five financial support for its state that come from their government are Croatia, Angola, Bosnia and Herzegovina, Lebanon, and Chili.

\section{Present Development of Landmine's in the World}

ICBL reports that in 2016, there are 232.000 antipersonnel mines were destroyed. Mostly, the destruction of antipersonnel mine was carried out in Afghanistan, Croatia, Iraq, and Cambodia. In May 2017, Mozambique has declared its country that its territory is free and clean of land mines 
or ERWs. Then, in February 2017, Algeria has declared itself that its territory has been cleared of land mines / ERWs.

In 2017, The Land Monitor has confirmed new findings about the use of antipersonnel mines in Myanmar and Syria (Research Team Leader, 2017). Anti-personnel mines has been used by the Myanmar government for 20 years and has been used by the Syrian government since 2012. Groups belonging to NSAGs (Non-State Armed Groups) such as Afghanistan, Yemen, Iraq, Nigeria, Ukraine have used anti-mining mines. NSAGs in Colombia have not used antipersonnel mines since the publication of Landmines Monitor in 1999. In Colombia, landmines have been used by Fuerzas Armadas Revolucionarias de Colombia-Ejército del Pueblo (FARC). In 2017, there was a ceasefire agreement by the Colombian government with the National Liberation Army (Union Camilista-Ejército de Liberación Nacional (ELN) (see Table 4).

Table 4: Stockpiles of Antipersonnel Mines

\begin{tabular}{ll}
$\begin{array}{l}\text { Largest stockpilers of antipersonnel } \\
\text { mines }\end{array}$ \\
\hline Russia & 26.5 million \\
\hline Pakistan & estimated 6 million \\
\hline India & estimated 4-5 million \\
\hline China & "Less than" 5 million \\
\hline US & 3 million \\
Total & 45 million
\end{tabular}

Source: Research Team Leader. 2017. Landmine Monitor 2017. Geneva: International Campaign to Ban Landmines. p. 8.

The table explains that until 2017, there are still states that doing stockpiling landmines. The state that doing stockpiling the largest number of landmines is Russia, which is 26.5 million. The second largest sequence is Pakistan, which is 6 million. The third largest order is India with approximately 4-5 million landmines. Then followed by China, which is around 5 million, and the United States which is 3 million.

The development of landmines stockpiling is there are more than 2.2 million landmines that have been destroyed in 2016. In Belarus for example, in 2017 there have been 3.4 million landmines destroyed. Then in Oman, in 2017 there are 3.052 landmines have destroyed. The last example is in Ukraine, in 2016 it destroyed 652.840 landmines type PFM (Research Team Leader, 2017). In Ukraine, the destruction of landmines is supported by the Ukrainian Ministry of Defense, NATO, Procurement Agency, and the Pavlograd Chemical Plant. Based on the data that reported by ICBL, in 2016 a total global clearance is around $170 \mathrm{~km}^{2}$ and 232.000 landmines has been destroyed.

\section{International Support for ICBL}

In its efforts to tackle the problem of landmines in the world, ICBL invites, encourages, and evenpresses the state to ratify or approve international treaties in 
reducing the use of landmine in their respective countries. ICBL's ability to deal with landmine problems can be said to be quite significant, because from year to year there is a reduction in the use of landmines in countries that have, hoard, and even produce landmines. Even though until now, there are still countries that do not want to ratify the agreement of the Mine Ban Treaty.

In its development, ICBL was strongly supported by the United Nations in its efforts to solve landmine problems. Since 1997, the annual UN General Assembly (UNGA) has strongly supported the ICBL, where this can be seen from the UN's efforts to fully support the existence of the Mine Ban Treaty. The UN is trying to push and pressure member states to ratify the agreement. Support from the United Nations for the ICBL can also be seen in 2016, which on $5^{\text {th }}$ December UNGA Resolution 71/34 emphasized the universalization and full implementation of the Mine Ban Treaty, which in this meeting was approved by 164 countries, without resistance, and 20 abstentions (Research Team Leader, 2017). Countries that abstained from voting on this agreement such as Nicaragua, Kuwait, Samoa, Cuba, Egypt, India, Iran, Israel, Myanmar, North Korea, Pakistan, Russia, South Korea, Syria, Uzbekistan, US and Vietnam.
The role of the United Nations in encouraging the Mine Ban Treaty is quite large and significant. In addition to UNGA, the UN supports the implementation of The Mine Ban Treaty through several programs through UN agencies. This can be demonstrated in the 2014-2021 Global Disability Action Plan program. This is a program from The World Health Organization (WHO), in which there is a contribution from the ICBL. This program implements important things that are supported by survivor networks, such as access to rural and remote rehabilitation, participation, social and economic inclusion, education, and psychological support. In 2017, WHO has released a healthrelated rehabilitation program. WHO plans that in 2030, they can fully implement the Sustainable Development Goals (SDGs). The 2013-2020 Mental Health Action Plan has also been carried out by WHO to deal with victims of landmine explosions. The SDGs program from the United Nations strongly supports the handling of casualties from landmines. This shows the seriousness of the UN in supporting the implementation of the Mine Ban Treaty.

In addition to the United Nations, there are many advocacy activities that support the ICBL in overcoming landmine problems. The 
support came from the Francophone Summit in Moncton, New Brunswick; the UN General Assembly in New York; the Special Summit of the European Council in the areas of Freedom, Security, and Justice in Finland; the Helsinki Summit of the European Union; the Organization of American States Summit; the Organization of the African Unity Summit; the Inter-Parliamentary Union; and the Assembly of African Francophone Parliamentarians.

\section{Challenges and Obstacles of the ICBL}

As an NGO engaged in security and humanitarian affairs, it has grown rapidly and has had a huge influence on the international community. However, in its efforts to deal with landmine issues, ICBL has experienced several obstacles and challenges, although most of the countries in the world have signed the agreement of The Mine Ban Treaty. These challenges and obstacles came from major countries who did not want to sign and ratify the international agreement on the Mine Ban Treaty. Major countries such as the United States, Russia, China, India, Saudi Arabia, Pakistan and Myanmar have not signed and ratified the agreement of The Mine Ban Treaty. This can be said that the international agreement has not been able to work.
The international regime still cannot apply internationally. These big countries are landmine-producing countries in the world. If these major countries have not been able to sign and ratify the agreement, it can be said that ICBL's efforts in dealing with landmine problems are still not maximized and effective

The United States has a very interesting geo-political and status position. The United States is often the main focus for many landmine activists. The position of the United States is very interesting because (i) in the last decade, the United States has done many things to avoid the use of landmine or production and help to clean up; (ii) on the other hand it opposes the agreement to ban the use of landmines.

In fact, the United States law banned the export of antipersonnel mines since October 1992, and in December 2007 the moratorium on landmine exports was extended to 2014. The United States has not used antipersonnel mines since 1991, or produced landmine production since 1997. ICBL also reported that the United States had contributed at least $\$ 796.8$ million to support mine action between 1999 and 2008 .

President Clinton in 1994, was the first leader to call for an international ban on the use of 
antipersonnel landmines. However, in 1997 at a meeting in Ottawa Canada to sign an agreement prohibiting the use of landmines, the United States was not present. They want the option to use landmines in a number of cases, such as along the demilitarized zone between North Korea and South Korea. In the perception of the United States, this will help defend South Korea. The United States' refusal to sign the agreement allows the United States to lay landmines anywhere, even though the United States supports landmine removal and humanitarian assistance for victims.

In the Clinton administration, he decided not to sign the agreement, but they set the goal of joining the ICBL in 2006. While in the Bush administration, he announced that in 2004 the United States would not approve the agreement. In the Obama administration at the end of November 2009, the Department of Foreign Affairs announced that it would not sign an anti-personnel landmine agreement in the next 10 years. However, due to a lot of direct criticism, the following day the Department of Foreign Affairs said that Washington's policy on this issue was being reviewed.

The United States is one of the largest producers, exporters and stockpiles of landmines. Where this situation is able to bring enormous profits to the United States. Landmines in the United States are the third largest after China and Russia. In 2002 for example, landmine deposits in the United States reached 1.56 million mines of non-self-destructing; 1.16 million M14 and M16 antipersonnel mines; and about 403,000 Claymore mines.

\section{CONCLUSION}

ICBL as an NGO that engaged in the humanitarian and security fields has made change of landmines in the international world today. It was able to ban the use of landmines and reduce landmine production. The Mine Ban Treaty agreed in 1997 was an agreement between the states in the world for banning the use of landmines and the production of landmines. There are many external supports for ICBL. This support came from the supranational organization namely the United Nations. Within the United Nations, support for the ICBL is included in the agenda of the UNGA (United Nations General Assembly) and UN agencies such as WHO also support the existence of ICBL.

Although the ICBL has made major changes regarding the prohibition on the use and production of landmines, it also still faces challenges and obstacles. These challenges and obstacles come from super power states. These states are 
the countries producing landmines. Countries such as the United States, Russia, China, Saudi Arabia, etc. do not want to sign and ratify the international agreement on the Mine Ban Treaty. Although the changes made by the ICBL are quite significant, it can be said that the ICBL in landmine's management has not been said to be effective. This is because the big states which producing landmine still do not want to sign and ratify the agreement of The Mine Ban Treaty.

\section{REFERENCES}

Anderson, Kenneth. (2000) 'The Ottawa Convention Banning Landmines, the Role of International NonGovernmental Organizations and the Idea of International Civil Society', EJIL, Vol. 11 No. 1, pp 91-120.

Human Rights Watch World Report. (2001) International Campaign to Ban Landmines. Human Rights Watch. Available at: http://www.hrw.org/wr2k1/ (Diakses: 2 Februari 2019).

ICRC. (2004) Ending the Landmine Era: Achievements and Challenges. Geneva: ICRC Publisher.

ICBL. (2013) Timeline of the International Campaign to Ban Landmines. Geneva.
ICBL. (2015) Landmine Monitor Myanmar/ Burma Report. Landmine \& Cluster Munition Monitor, pp 1-29.

ICBL. (2004) 'Landmines Update: Ban Mines, Clear Mines, Help Survivor', Issue 12, pp. 1-8.

ICBL. (2017) 2017 Operational Plan. Geneva, Switzerland: Cluster Munition Coalition.

International save the Children Alliances. (2000) Working Paper Child Landmine Survivors: An Inclusive Approach to Policy and Practice, No. 2, London: Save the Children Federation.

Neufeld, A. (2000) Building a Norm: The Banning of Anti-Personnel of Landmines. Thesis. Canada: Department of Political Science Simon Fraser University.

Peters, A. (t.t) International Partnership on the Road to Ban Anti-Personnel Landmines. USA: Global Public Policy Networks.

Research Team Leader. (2015) Landmine Monitor 2015. Geneva: International Campaign to Ban Landmines.

Research Team Leader. (2016) Landmine Monitor 2016. Geneva: International Campaign to Ban Landmines.

Research Team Leader. (2017). Landmine Monitor 2017. Geneva: International Campaign to Ban Landmines.

Shah, A. (2009) Landmines. Available at: http://www.globalissues.org/article/7 9/landmines (Diakses: 2 Februari 2019). 